Al-Huquq: Journal of Indonesian Islamic Economic Law, 3 (2), 2021: 185 - 210

ISSN: 2715-0003; E-ISSN 2714-5514

DOI: http://doi.org/10.19105/alhuquq.v3i2.5013

\title{
Menjaga Stabilitas Usaha Pasca Pandemi Covid-19 dengan Penerapan Akad Murabahah pada Pelaksanaan Investasi Syariah
}

\author{
Moh. Hamzah \\ (Fakultas Syariah dan Hukum Universitas Islam Negeri Sunan Kalijaga \\ Yogyakarta, Jl. Marsda Adisucipto Yogyakara, 55281)
}

\begin{abstract}
Abstrak:
Indonesia yang menjadi salah satu Negara di asia yang terdampak pandemi Covid-19 ini, baik dari sektor kesehatan, pendidikan dan sektor-sektor penting lainnya. Bahkan pada sektor ekonomipun menjadi sasaran dari dampak pandemi Covid-19 tersebut, sehingga banyak perusahaan, pabrik dan beberapa pelaku ekonomi mengalami kerugian yang cukup besar. Selain itu, dampak dari pandemi Covid-19 ini menyebabkan rendahnya sentiment investor terhadap pasar yang pada endingnya membawa pasar ke arah cenderung negative. Untuk mengurai kekhawatiran para investor tersebut, dalam penelitian ini akan memberikan sebuah konsep untuk menjaga stabilitas usaha pada pelaksanaan investasi. Dalam mempertegas content pada penelitian ini, terdapat tiga pokok permasalah yang akan dijawab, yaitu bagaimana perspektif hukum Islam tentang investasi, bagaimana tinjauan umum tentang akad murabahah, serta bagaimana cara menjaga stabilitas usaha dengan penerapan akad murabahah pada pelaksanaan investasi syariah. Penelitian yang merupakan jenis penelitian normatif ini akan menggunakan metode pendekatan konseptual, serta teknik analisis data bersifat analisis deskriptive dan argumentative. Dengan harapan bahwa konsep ini akan memberikan dampak yang positif terhadap perkembangan ekonomi dan terwujudnya kemaslahatan, serta terciptanya masyarakat adil makmur yang diridhoi Allah SWT. (Indonesia which is one of the countries in Asia that has been effected by the covid -19 pandemic, both from the health sector, education and other important sectors. Even in the economic sector was targeted by the impact of the Covid-19 pandemic, so that many companies, factories and some economic actors suffered considerable losses. In addition, the impact of covid-19 pandemic caused low investor sentiment towards the market
\end{abstract}

email koresproden mohhamzahh262@gmail.com

https://creativecommons.org/licenses/by-nc/4.0/

Copyright (c) 2019 by al-huquq. All Right Reserved 
which in the end led the market to tend to be negative. To unravel the concerns of these investors, in this study will provide a concept to maintain business stability in the implementation of investments. In emphasizing the content of this research, there are three main issues that Will be answered, namely how is the perspective of islamic law on Investment, how is an overview of murabahah contracts, and how to maintain business stability by implementing murabahah contracts in the implementation of Sharia investment. Reseach which is a type of normative research will use conceptual approach methods, as well as descriptive and argumentative data analysis techniques. It is hoped that this concept will have a positive impact on economic development and the realization of benefits, as well as the cration of a just and prosperous society blessed by Allah SWT).

Kata Kunci:

Covid-19, Murabahah, Investasi Syariah

\section{Pendahuluan}

Kasus penyebaran virus Covid-19 (Corona Virus Diseasi 2019) yang menyebabkan dampak yang sangat besar terhadap sektor kesehatan, yang terbilang sangat mengkhawatirkan karena jumlah pasien yang setiap hari semakin bertambah dan sektor pendidikan yang tidak teralu efektif karena tidak bisa belajar langsung di sekolah. Bahkan dampak yang paling dirasakan yaitu pada sektor ekonomi yang berpotensi akan mengganggu kinerja keuangan, juga membuat perlambatan perekonomian di Indonesia.

Penyebaran dan peningkatan jumlah kasus Covid-19 terjadi dengan waktu yang sangat cepat dan telah menyebar di berbagai Negara termasuk Indonesia. sampai bulan agustus tahun 2020, dilaporkan total kasus terkonfirmasi 17.660.523 kasus dengan 680.894 kematian dimana kasus dilaporkan di 216 Negara (WHO, 2020). Sedangkan di Indonesia kasus terkonfirmasi sebanyak 165. 887 dengan 7.169 kematian di 34 provinsi (Kemenkes RI, 2020). ${ }^{1}$

\footnotetext{
1 Fakhrul Rozi Yamali and Ririn Noviyanti Putri, ‘Dampak Covid-19 Terhadap Ekonomi Indonesia', Ekonomis: Journal of Economics and Business, 4.2 (2020), 384 <https://doi.org/10.33087/ekonomis.v4i2.179>.
} 
Dari sekian banyak dampak yang terjadi dan kegelisahan rakyat indonesia terkhusus pada pengusaha atau pemilik modal, pemerintah Indonesia merespon dengan cepat dampak pandemi Covid-19 pada sektor ekonomi dan keuangan melalui penguatan Lembaga Keuangan Syariah (LKS). Hal ini dilakukan oleh pemerintah Indonesia, mengingat kinerja Lembaga Keuangan Syariah yang begitu baik dan pesatnya kemajuan yang terjadi pada lembaga keuangan tersebut. seperti apa yang sudah banyak dikenal dan diketahui, Lembaga Keuangan Syariah yang merupakan salah satu sistem intermediasi keuangan nasional, juga sangat berperan penting dalam setiap kebijakan stimulus perekonomian di Indonesia atau nasional melalui berbagai produk pembiayaan yang pada pelaksanaanya menggunakan sistem syariah.

Salah satunya pada pelaksanaan penanaman modal atau investasi pada Lembaga Keuangan Syariah. Investasi sendiri merupakan suatu kegiatan yang diperbolehkan bahkan dianjurkan dalam ajaran agama Islam. Hal ini dikarenakan kegiatan investasi ini sudah dilakukan oleh Nabi Mohammad Saw, yang pada masa hidupnya beliau sering meakukan kegiatan tersebut, bahkan dari sejak Nabi Mohammad masih muda sampai menjelang masa kerasulannya.

Investasi secara sederhana dapat diartikan sebagai kegiatan yang bertujuan untuk mengembangkan harta. ${ }^{2}$ Investasi merupakan bagian dari fikih muamalah, maka berlaku kaidah hukum asal dalam semua bentuk muamalah adalah boleh dilakukan kecuali ada dalil yang mengharamkannya. ${ }^{3}$ Selain itu, kegiatan investasi adalah sebuah maslahah multiplayer effect, yang pada esensinya akan terciptanya sebuah lapangan usaha yang berpotensi menghasilkan laba yang halal dan lapangan pekerjaan yang dapat dimanfaatkan oleh sejuamlah orang untuk mencukupi kehidupannya, serta menghindari mengendapnya harta yang dimiliki dan meminimalisir perputaran harta diantara orang kaya saja.

\footnotetext{
2 Mardhiyah Haryati, 'Investasi Menurut Perspektif Ekonomi Islam', Journal of $\begin{array}{lllll}\text { IslamicEconomics and } & \text { Business), } & 1.1 & \text { (2016), }\end{array}$ <http://ejournal.radenintan.ac.id/index.php/ikonomika>.

${ }^{3}$ A Djazuli, Kaidah-Kaidah Fikih: Kaidah Hukum Islam Dalam Menyelesaikan MasalahMaslah Yang Praktis (Jakarta: Kencana, 2006), 31.
} 
Dampak pandemi Covid-19 menyebabkan rendahnya sentiment investor terhadap pasar yang pada akhirnya membawa pasar ke arah cenderung negatif. ${ }^{4}$ Karenanya, peneliti akan memberikan konsep baru untuk bagaimana pada nantinya konsep tersebut bisa digunakan untuk mengurai rasa kekhawatiran yang ada, yakni dengan penerapan akad murabahah pada pelaksanaan usaha dalam investasi yang dilakukan oleh investor. Dimana akad murabahah adalah jual beli dengan harga perolehan disertai tambahan sebagai keuntungan. Oleh karena itu, penulis didorong untuk mengkaji lebih dalam lagi dan melakukan penelitian dengan judul "Menjaga Stabilitas Usaha dengan Penerapan Akad Murabahah Pada Pelaksanaan Investasi Syariah".

Selanjutnya, untuk mempertegas content dari penelitian ini, maka penulis memberikan tiga pokok masalah untuk bagaimana pada nantinya akan dikaji secara mendalam. Pertama, bagaimana perspektif hukum Islam tentang investasi. Kedua, bagaimana tinjauan umum tentang akad murabahah. Ketiga, bagaimana cara menjaga stabilitas usaha dengan penerapan akad murabahah pada pelaksanaan investasi syariah.

\section{Metode Penelitian}

Penelitian ini merupakan jenis penelitian hukum normatif dengan menggunakan pendekatan konseptual (conceptual approach). Penelitian normatif adalah suatu penelitian hukum yang dilakukan dengan cara meneliti bahan pustaka atau data skunder. ${ }^{5}$ Dari beberapa perspektif lain, mengatakan bahwa penelitian hukum normatif disebut juga penelitian hukum doctrinal. ${ }^{6}$ Dengan artian, bahwa dalam penelitian yang dilaksanakan dengan menggunakan literatur (kepustakaan), baik berupa buku dan artikel maupun laporan hasil penelitian dari penelitian terdahulu yang berkaitan dengan pokok penelitian ini. Adapaun yang menjadi sumber primer pada penelitian ini adalah al-Qur'an dan al-Hadits. Sedangkan

4 Dito Aditia Darma Nasution, Erlina Erlina, and Iskandar Muda, 'Dampak Pandemi COVID-19 Terhadap Perekonomian Indonesia', Jurnal Benefita, 5.2 (2020), 212 <https://doi.org/10.22216/jbe.v5i2.5313>.

5 Soerjono Soekanto and Sri Mamudji, Penelitian Hukum Normatif: Suatu Tinjauan Singkat (Jakarta: PT. Raja Grafindo Persada, 2003), 13.

${ }^{6}$ Peter Mahmud Marzuki, Penelitian Hukum (Jakarta: Kencana Prenada Media, 2010), 35. 
Menjaga Stabilitas Usaha Pasca Pandemi Covid-19 dengan Penerapan Akad Murabahah pada Pelaksanaan Investasi Syariah

sumber data skunder dalam penelitian ini adalah Kompilasi Hukum Ekonomi Syariah, Undang-Undang, Fatwa Dewan Syariah Nasional Majelis Ulama Indonesia, jurnal dan buku-buku yang berkaitan langsung dengan investasi dan pelaksanaan akad murabahah.

Selain itu, pendekatan konseptual (conceptual approach) yang dimaksudkan untuk menganalisa bahan hukum sehingga akan mendapatkan makna yang terkandung dalam istilah-istilah hukum. ${ }^{7}$ Dengan pendekatan konseptual ini nantinya akan mampu meghadirkan atau memunculkan hal-hal menarik dari perspektif pengetahuan yang praktis. Sehingga pada endingnya bisa menetapkan nilainya (makna) secara tepat dan bisa di aplikasikan dan diimplementasikan dalam proses pemikiran dengan mengidentifikasi pada perspektif, prinsip dan doktrin yang sebelumnya sudah ada untuk kemudian akan melahirkan ide dan gagasan baru.

Sedangkan teknik analisis data pada penelitian ini bersifat analisis deskriptif dan argumentative. ${ }^{8}$ Dengan bentuk analisis data tersebut, diharapkan penelitian yang dilaksanakan akan lebih mudah dan akan memperoleh suatu temuan yang berdasarkan pada fokus permasalahan yang ingin dijawab. Kesimpulan diperoleh setelah merujuk kembali pada identifikasi topik (rumusan masalah), orientasi penelitian dan pembahasan.

\section{Investasi dalam Perspektif Islam}

Investasi berasal dari bahasa Inggris investment dari kata dasar invest yang berarti menanam, atau istathmara dalam bahasa Arab, yang berarti menjadikan, berbuah, berkembang dan bertambah jumlahnya. ${ }^{9}$ Investasi adalah suatu kometmen atas suatu modal pada saat ini, dengan berorientasi pada keuntungan yang akan didapatkan pada masa yang akan datang. ${ }^{10}$ Investasi ini merupakan suatu bentuk usaha yang dilakukan oleh seseorang atau kelompok dalam

7 Hajar M, Model-Model Pendekatan Dalam Penelitian Hukum Dan Figh (Pekanbaru: UIN Suska Riau, 2015), 41.

8 Sandu Siyoto and Ali Sodik, Dasar Metodologi Penelitian (Yogyakarta: Literasi Media Publishing, 2015), 122.

${ }^{9}$ Elif Pardiansyah, 'Investasi Dalam Perspektif Ekonomi Islam: Pendekatan Teoritis

Dan Empiris', Economica: Jurnal Ekonomi Islam, $8.2 \quad$ (2017), 355 <https://doi.org/10.21580/economica.2017.8.2.1920>.

10 Eduardus Tandelilin, Portofolio Dan Investasi: Teori Dan Aplikasi (Yogyakarta: Kanisius, 2010), 2. 
mendapatkan suatu keuntungan atau penghasilan, dimana hal tersebut akan didapat jika orang tersebut terlebih dahulu menanamkan sejumlah uang atau modal kepada pihak lain untuk dikelola.

Hakekat investasi pada prinsipnya sama dengan menabung. ${ }^{11}$ Kasmir dan Jakfar berpendapat, bahwa investasi dapat diartikan sebagai penanaman modal dalam suatu kegiatan yang memiliki jangka waktu relatif panjang dalam berbagai bidang usaha atau proyek yang membutuhkan dana dengan tujuan memperoleh keuntungan. ${ }^{12}$ sedangkan Menurut Sadono Sukirno, memungkinkan suatu masyarakat terus menerus meningkatkan pendapatan nasional dan meningkatkan taraf kemakmuran masyarakat, serta meningkatkan kegiatan ekonomi dan kesempatan kerja, merupakan suatu orientasi dari kegiatan berinvestasi. ${ }^{13}$ Kegiatan ini menurut Sadono Sukirno, Kasmir dan Jakfar, pada esensinya merupakan suatu upaya untuk meningkatkan taraf kehidupan ekonomi. Dimana masyarakat mampu untuk lebih kreatif dalam mengulah dana sehingga menghasilkan keuntungan yang dapat dimanfaatkan pada masa yang akan datang.

Menambah suatu modal dalam perekonomian yang akan digunakan untuk memproduksi barang-barang dan jasa di masa depan dan pengeluaran untuk membeli barang-barang modal dan peralatan peralatan produksi dengan tujuan untuk mengganti adalah pengertian investasi menurut perhitungan pendapatan nasional. ${ }^{14}$ Pembelian suatu barang yang sekiranya memberikan sesuatu yang menghasilkan margin atau keutungan yang akan datang merupakan bentuk dari tujuan pengeluaran dana atau uang untuk investasi. Artinya, pertimbangan yang diambil oleh pengusaha atau perusahaan dalam memutuskan membeli atau tidak membeli barang dan jasa tersebut adalah harapan dari pengusaha atau perusahaan akan

\footnotetext{
11 Ricko Mahadani, Investasi Emas Batangan Untuk Orang Gajian (Yogyakarta: Khitah Publishing, 2012), 39.

12 Kasmir and Jakfar, Studi Kelayakan Bisnis (Jakarta: Kencana Prenada Media, 2015), 32.

13 Sadono Sukirno, Pengantar Teori Makro Ekonomi (Jakarta: PT. Raja Grafindo Persada, 2003), 98.

14 Pardiansyah, 'Investasi Dalam Perspektif Ekonomi Islam: Pendekatan Teoritis Dan Empiris', 341.
} 
Menjaga Stabilitas Usaha Pasca Pandemi Covid-19 dengan Penerapan Akad Murabahah pada Pelaksanaan Investasi Syariah

kemungkinan keuntungan yang dapat diperoleh. Harapan keuntungan ini merupakan faktor utama dalam investasi.

Investasi syariah merupakan investasi yang didasarkan pada prinsip-prinsip syariah, baik investasi pada sektor riil maupun sektor keuangan. Sehingga investasi tidak dapat dilepaskan dari prinsipprinsip syariah. ${ }^{15}$ Investasi syariah adalah sebuah investasi berbasis syariah yang menggunakan instrument islam dalam pelaksanaannya. ${ }^{16}$ Sehingga dari definisi syariah tersebut, bisa dipahami bahwa orientasi atau niat spekulasi dalam kegiatan bisnis dan suatu investasi pada dasarnya tidak boleh bertentangan dengan hukum syariah. Kemungkinan besar atas untung atau rugi suatu usaha dalam kegiatan investasi, merupakan sesuatu yang tidak bisa dilepaskan pada setiap aktivitas ekonomi yang dilakukan. Terlepas dari kegiatan yang menghasilkan untung atau rugi tersebut, tentunya manusia memiliki hak untuk dalam menentukan pilihan investasi usahanya. Karena, setiap kegiatan usaha ekonomi pasti memiliki ketidak pastian dalam untung atau rugi. karenanya perlu sikap kompeten dalam menekuni usaha yang dilakukan, serta mampu untuk menerima segala resiko yang akan diterima setelahnya.

Dalam Pasal 586 ayat 1 Kompilasi Hukum Ekonomi Syariah, ditegaskan bahwa pemilihan dan pelaksanaan transaksi investasi dilaksanakan menurut prinsip kehati-hatian, serta tidak diperbolehkan melakukan spekulasi yang di dalamnya mengandung unsur penipuan. ${ }^{17}$ Peraturan ini mempertegas bahwa di dalam kegiatan investasi dituntut untuk lebih hati-hati dan memikirkan untung ruginya, serta manusia diharuskan mampu untuk memilih kegiatan usaha yang akan dilakukan dengan tetap berpedoman pada nash dan sunnah. Yakni dengan artian, bahwa kegiatan dalam investasi tidak diperkenankan untuk melakukan transaksi ekonomi yang mengandung larangan dari Syariah, contohnya pekerjanpekerjaan yang mengandung riba, gharar dan kegiatan ekonomi terlarang lainnya. Karena pada sayogyanya, Islam telah mengatur

\footnotetext{
15 Pardiansyah, 356.

${ }^{16}$ Hendro Lisa and Martina Napratilora, 'Sosialisasi Investasi Syariah Di Masyarakat', AL-MUQAYYAD: Jurnal Ekonomi Syariah, $3.1 \quad$ (2020), 18-43 <https://doi.org/10.46963/jam.v3i1.152>.

17 Pusat Pengkajian Hukum Islam Masyarakat Madani, Kompilasi Hukum Ekonomi Syariah (Jakarta: Kencana, 2017), 168.
} 
secara penuh dan serius tentang suatu mekanisme dalam mengembangkan harta yang dimiliki oleh manusia, serta salah satu usaha dalam pengembangan harta kekayaan tersebut adalah melalui kegiatan investasi yang baik dan benar sesuai dengan syariat Islam.

Pada eksistensinya, peranan dari kegiatan investasi terdapat tiga fungsi penting dalam kegiatan ini, yaitu: Pertama, investasi selalu diikuti oleh perkembangan teknologi. Kedua, pertambahan barang modal sebagai akibat investasi akan menambah kapasitas produksi. Dan ketiga, investasi merupakan salah satu komponen dari pengeluaran agregat, sehingga kenaikan investasi akan meningkatkan permintaan agregat, pendapatan nasional serta kesempatan kerja.

Islam mengajarkan untuk berinvestasi dan mengembangkan harta, namun tetap dalam aturan-aturan yang tidak bertentangan dengan al-Quran dan as-Sunnah. ${ }^{18}$ Dalam ekonomi Islam, investasi merupakan kegiatan muamalah yang sangat dianjurkan, karena dengan berinvestasi harta yang dimiliki menjadi produktif dan juga mendatangkan manfaat bagi orang lain. ${ }^{19}$ Islam memiliki sistem perekonomian yang diselenggarakan dalam rangka mewujudkan kesejahteraan kehidupan manusia baik secara material maupun non material, dimana hal ini dipertegas dengan beberapa dalil-dalil, baik yang berupa Al-Qur'an, al-Hadits, ijma' dan dalil-dalil lainnya yang semuanya dengan tegas melarang aktivitas penimbunan (ihtikar) terhadap harta yang dimiliki.

Secara umum, prinsip bagi hasil dalam kegiatan investasi dalam Islam dapat dilakukan dengan empat akad, yaitu al-musyarakah, almudharabah, al-muzara'ah dan al-musaqah. Akan tetapi, sejauh ini akad al-musyarakah dan al-mudharabahlah yang sering dipakai dalam kegiatan investasi. Karena akad al-muzara'ah dan al-musaqah dikhususan pada pembiayaan pertanian atau plantation financing oleh beberapa pelaku ekonomi Islam.

Al-musyarakah adalah akad kerjasama antara dua pihak atau lebih untuk suatu usaha tertentu, dimana masing-masiig pihak memberikan konstribusi dana dengan kesepakatan bahwa

\footnotetext{
${ }_{18}$ Muhammad Syahbudi and Elida Elfi Barus, 'Mewujudkan Masyarakat Yang Sadar Investasi Syariah', Junal Ilmu Ekonomi Dan Keislaman, 7.2 (2019), 208-23.

19 Pardiansyah, 'Investasi Dalam Perspektif Ekonomi Islam: Pendekatan Teoritis Dan Empiris', 355.
} 
Menjaga Stabilitas Usaha Pasca Pandemi Covid-19 dengan Penerapan Akad Murabahah pada

Pelaksanaan Investasi Syariah

keuntungan dan resiko akan ditanggung bersama denga kesepakatan. ${ }^{20}$ Sedangan al-mudharabah adalah akad diantara dua belah pihak, dimana pihak yang satu menyerahkan modal dan pihak yang lainnya memperdayakan modal tersebut untuk usaha, serta keuntungan yang diperoleh akan dibagi bersama dengan porsi yang telah disepakati pada saat akad. ${ }^{21}$ Karenanya terdapat perbedaan pada dua akad di atas (al-mudharabah dan al-musyarakah), dimana letak perbedaannya yaitu pada penanaman modal. Mudharabah modal usaha dihasilkan dari satu pihak dan pihak lainnya bertugas untuk mengelola modal tersebut, sedangkan musyarakah modal dihasilkan dari kedua belah pihak, namun untuk keuntungan atau kerugian tergantung pada bagaimana akad yang telah dijanjikan di awal.

Ada beberapa prinsip syariah khusus terkait investasi yang harus menjadi pegangan bagi para investor dalam berinvestasi, yaitu:22

1. Keadilan pendistribusian pendapatan.

2. Transaksi dilakukan tanpa ada paksaan, dengan kata lain harus atas dasar rida sama rida ('antarodin).

3. Tidak ada unsur gharar (tidak jelas), darar (kerusakan/kemudaratan), tadlis (penipuan), riba, maysir (perjudian) dan tidak mengandung kemaksiatan.

4. Tidak mencari rezeki pada sektor usaha haram, baik dari segi zatnya (objeknya) maupun prosesnya (memperoleh, mengolah dan medistribusikan), serta tidak mempergunakan untuk hal-hal yang haram.

5. Tidak menzalimi dan tidak pula dizalimi (la tazlimun wa la tuzlamun).

Pada dasarnya prinsip-prinsip yang dikemukakan di atas adalah bentuk dari saripati dari sumber rujukan utama dalam ajaran Islam, yaitu al-Qur'an dan al-Hadits. Yang lambat laun mulai dielaborasikan oleh para ulama fiqih agar pada nantinya hal tersebut

\footnotetext{
20 Trimulato Trimulato, 'Analisis Potensi Produk Musyarakah Terhadap Pembiayaan Sektor Riil Umkm', Jurnal Ekonomi \& Studi Pembangunan, 18.1 (2017), 41-51 <https://doi.org/10.18196/jesp.18.1.3830>.

${ }^{21}$ Muhammad Fahmul Iltiham, 'Implementasi Akad Mudharabah Berdasarkan PSAK 105 Tentang Akuntansi Mudharabah Dan Fatwa DSN MUI Pada Produk Pembiayaan', Jurnal Ekonomi Islam, 11.1 (2019), 21-38.

22 Abdul Aziz, Manajemen Investasi Syariah (Bandung: Alfabeta, 2010), 16.
} 
mudah dan gampang dipahami oleh semua kalangan dan diimplementasikan dalam segala kegiatan ekonomi dan bisnis Islam. Berdiri atas landasan dan asas tersebut, prinsip syariah yang diatur oleh Fatwa Dewan Syariah Nasional Majelis Ulama Indonesia (DSNMUI) sebagai lembaga yang dilegalkan oleh pemerintah Indonesia untuk mengeluarkan fatwa-fatwa terkait dengan akifitas ekonomi dan bisnis yang sesuai dengan jaran islam. Fatwa DSN-MUI memiliki ranah kekuasaan untuk mengatur berbagai macam-macam transaksi ekonomi, siklus keuangan dan pengeolaan bisnis termasuk didalamnya kegiatan investasi, agar pada endingnya bisa sesuai dan selaras dengan koridor syariah.

Secara khusus fatwa No. 80/DSN-MUI/III/2011 mengatur bagaimana memilih investasi yang dibolehkan syariat dan melarang kegiatan yang bertentangan dengan prinsip syariah dalam kegiatan investasi dan bisnis. ${ }^{23}$ Setidaknya terdapat lima belas larangan yang dikemukakan dalam fatwa ini, dimana lima belas larangan tersebut dapat dipahami sebagai berikut:

1. Melakukan jual beli atau sebagainya atas barang yang belum dimiliki oleh para pihak atau bisa disebut dengan Bay'i ma'dum.

2. Memperjual belikan barang yang tidak dibenarkan oleh syariat Islam, serta jual beli dimana rukun dan akadnya tidak sesuai (baik dari ketentuan asal, sifat dan pokokpokonya).

3. Melakukan transaksi (dalam jual beli dan lain sebagainya) yang tidak memiliki kepastian yang jelas dalam akad yang dilakukan, hal ini meliputi kuantitas atau kualitas dari suatu barang, ataupun terkait denga penyerahan dari objek akad tersebut. Transaksi ini dikatagorikansebagai transaksi yang bersifat gharar.

4. Sesuatu yang menimbulkan maysir, dimana dalam kegiatan ini akan hanya menguntungkan satu pihak dan merugikan pihak yang satunya. Karena dalam kegiatan ini melibatkan perjudian, dimana pihak yang lebih unggul atau memenangkan perjudian tersebut akan memperoleh taruhannya tersebut.

\footnotetext{
${ }^{23}$ Fatwa Dewan Syari'ah Nasional, 'Fatwa DSN Mekanisme Perdagangan Efek', 2011.
} 
5. Menimbun barang yang sedang langka atau ikhtikar, kegiatan ini terjadi saat barang berada pada harga mahal dan menimbunnya dengan tujuan untuk menjual kembali pada saat harganya lebih mahal, sedangkan disisi lain barang tersebut merupakan barang yang sangat dibutuhkan masyarakat (barang pokok).

6. Kegiatan riba, yaitu suatu tambahan yang diberikan atas pokok utang dengan imbalan penangguhan imbalan secara mutlak, serta tambahan yang diberikan dalam pertukaran barang-barang ribawi (al-amwal al-ribawiyyah).

7. Kegiatan Taghrir, yakni sebuah upaya yang berupa ucapan maupun tindakan yang mengandung kebohongan, dengan maksud untuk mempengaruhi orang lain agar terdorong untuk melakukan transaksi.

8. Tadlis, yakni tindakan seorang penjual untuk mengelabui pembeli seolah-olah objek akad yang ditransaksikan tidak cacat, sedangkan pada kenyataannya barang tersebut sudah cacat. akan tetapi penjual menyembunyikan kecacatan tersebut untuk memperoleh hasil yang lebih banyak.

9. kegiatan yang merupakan bagian dari tadlis, Ghishsh yaitu penjual yang menyembunyikan kecacatan suatu barang atau objek akad dengan melayangkan suatu pemaparan dari keunggulan atau keistimewaan barang yang dijual.

10. Kegiatan tukar menukar barang dalam suatu transaksi (akad), dimana secara kuantitas dan kualitas barang (objek) yang dipertukarkan tidak memiliki keseimbangan. Kegiatan ini merupkan suatu kegiatan ghabn.

11. Adakalanya Talaqqi al-rukban, yaitu salah satu kegiatan yang merupakan bagian dari ghabn. Kegiatan ini yaitu seorang penjual yang menjual barangnya jauh lebih murah dari harga pasar, yang dikarenakan penjual sendiri tidak mengetahui secara pasti harga pasar yang ada pada waktu tersebut.

12. Tanajush/Najsh, yaitu suatu upaya untuk menimbulkan kesan kepada banyak pihak yang berminat untuk membelinya, dengan cara menawar barang dangan harga lebih tinggi oleh pihak yang tidak bermaksud membelinya. 
13. Kegiatan yang membenarkan yang batil dan menjadikan yang batil sebagai sesuatu yang benar, dengan maksud untuk mengambil sesuatu yang bukan haknya. Kegiatan ini dikatagorikan sebagai kegiatan Rishwah.

14. Dharar, atau tindakan yang dapat menimbulkan kerugian bagi pihak lain dan hadirnya suatu bahaya.

15. Suatu perbuatan yang dianggap sebagai salah satu bentuk penganiayaan, dalam hal ini berupa perbuatan mengambil, merugikan, menghalangi hak orang lain yang tidak dibenarkan oleh Syariah. Selain itu, perbuatan ini juga tergolong ada perbuatan maksiat dan zalim.

Dari beberapa prinsip syariah dalam berinvestasi yang telah dikemukakan di atas. Secara umum dapat dipahami bahwa dalam melakukan investasi harus dilakukan dengan transparan, jelas dan tanpa adanya keterpaksaan di antara para pihak, sehingga akan terciptanya keikhlasan dan kerelaan. Selain itu, harus saling menguntungkan satu sama lain dan yang harus di titik beratkan pada kegiatan investasi tersebut, yaitu bahwa dalam kegiatan investasi yang dilakukan bukan termasuk keharaman, baik dari segi cara ataupun zat.

Islam memberikan pemahaman yang sangat besar terhadap umatnya, untuk berusaha semaksimal mungin dalam menghasilkan kebahagiaan di dunia dan akhirat. Memperoleh kehidupan yang baik di dunia dan akhirat ini yang akan menjamin tercapainya suatu kesejahteraan lahir dan batin (falah). ${ }^{24}$ Oleh karena itu, upaya untuk terwujudnya dan tercapainya rasa kebahagiaan dan kesejahteraan tersebut, salah satunya dengan mengaplikasikan kegiatan investasi.

Namun untuk mengamini akan terciptanya kebahagiaan di dunia dan akhirat pada pelaksanaan investasi, Islam memberikan rambu-rambu atau batasan dalam investasi, dengan maksud untuk memberikan pengarahan mana yang diperbolehkan dan mana yang dilarang dalam hukum syariah. karenanya, agar kegiatan investasi yang dijalankan tidak hanya berorientasi pada banyak atau sedikitnya hasil yang akan didapatkan, melainkan bagaimana pada endingnya nanti investasi yang dijalankan dapat bernilai ibadah.

24 Aziz, Manajemen Investasi Syariah, 14. 
Ada beberapa ayat al-Qur'an yang dijadikan sebagai landasan hukum dalam kegiatan investasi dan ayat tersebut yang memberikan seruan untuk melaksanakan kegiatan investasi. ayat tersebut, antara lain QS. al-Hasyr (59) : 18 dan QS. al-Baqarah : (2) : 261 sebagai berikut;

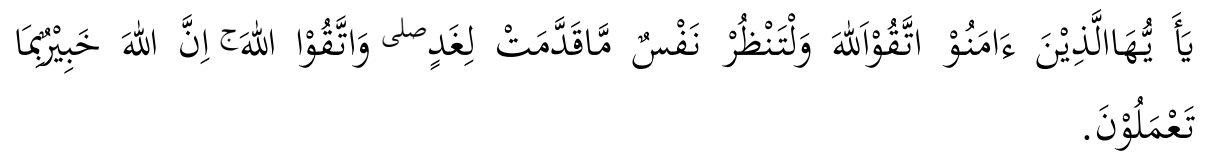

"Hai orang-orang yang beriman, bertakwalah kepada Allah dan hendaklah setiap diri memperhatikan apa yang telah diperbuatnya untuk hari esok (akhirat); dan bertakwalah kepada Allah, sesungguhnya Allah maha mengetahui apa yang kamu kerjakan." 25

Dari ayat di atas dapat dipahami bahwa, Islam sangat menganjurkan kepada umat-Nya untuk lebih kreatif dalam menjalani kehidupan untuk begaimana pada nantinya bisa dijadikan sebagai bekal di alam akhirat nanti. selain itu, ayat tersebut mengandung anjuran berinvestasi dengan baik dan benar. Kendati demikian, dalam Islam semua jenis keiatan jika diniatkan sebagai suatu ibadah dan rasa takwa kepada sang Pencipta, maka hal tersebut juga bernilai suatu ibadah yang bisa dijadikan sebagai bekal di dunia dan akhirat, salah satunya yaitu dengan kegiatan investasi. Kemudian kandungan ayat QS. al-Baqarah : 261

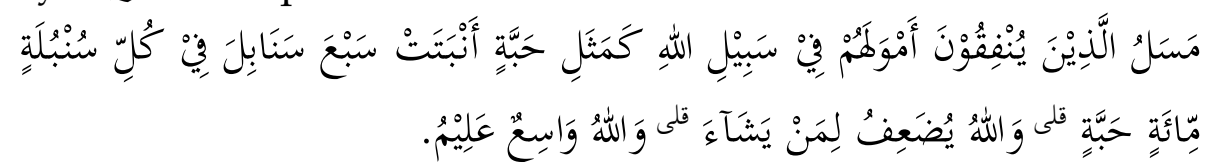

"Perumpamaan (nafkah yang dikeluarkan oleh) orang-orang yang menafkahkan hartanya di jalan Allah adalah serupa dengan sebutir benih yang menumbuhkan tujuh bulir, pada tiap-tiap bulir seratus biji. Allah melipat gandakan (ganjaran) bagi siapa yang dia kehendaki. Dan Allah maha luas (karunia-Nya) lagi maha mengetahui. ${ }^{26}$

Ayat tersebut merupakan suatu gambaran atau informasi terkait dengan pentingnya perbuatan investasi walaupun secara implisit tidak berbicara tentang investasi langsung, karena yang tersurat dalam dalam ayat tersebut yaitu betapa pentingnya menginfakkan

\footnotetext{
${ }^{25}$ QS. Al-Hasyr (59): 18.
}

${ }^{26}$ QS. Al-Baqarah (2): 261. 
harta di jalan Allah. Akan tetapi ketika dilihat dari perspektif ekonomi syariah, kegiatan ini akan memberikan pengaruh yang besar dalam kehidupan di dunia. Dengan demikian, dapat dipahami bahwa infak yang dimaksud merupakan suatu kegiatan yang dilakukan oleh seseorang dalam bentuk investasi, kemudian hasil dari investasi tersebut disalurkan kepada hal-hal yang produktif dan dikira perlu, maka kegiatan investasi tersebut akan bernilai kebaikan dan pahala yang akan dijadikan sebagai bekal dalam hidup di dunia dan akhirat.

Dari uraian di atas dapat ditarik benang mirahnya bahwa kegiatan investasi dalam pandangan Islam adalah kegiatan yang diperbolehkan dan sangat penting untuk dilakukan, serta perlu untuk dipersiapkan secara matang dan benar. Hal ini sebagaimana yang telah tersirat di dalam al-Qur'an surat al-Hasyr ayat 18, yang secara tegas memerintahkan agar orang-orang beriman untuk mempersiapkan diri untuk dijadikan sebagai bekal untuk hari esok. Adapun persiapan yang dimaksud, salah satunya yaitu dengan kegiatan investasi.

Oleh karena itu, untuk terhindar dari kegiatan-kegiatan investasi yang tidak Islami atau tidak dibenarkan oleh syariat, tentu sangat perlu untuk paham dan mengerti etika bisnis dalam berinvestasi. Karena ketidak tahuan dan kemalasan dalam mencari tahu tentang etika berinvestasi dalam Islam terkadang membuat orang terjerumus dalam perbuatan investasi yang diharamkan atau investasi yang sudah keluar dari koridor Islam. Sendati demikian, dikarenakan adanya iming-iming laba yang lebih besar.

\section{Tinjauan Umum Akad Jual Beli Murabahah}

Pembiayaan adalah kemampuan untuk melaksanakan suatu pembelian atau mengadakan suatu pinjaman dengan suatu janji pembayarannya akan dilakukan ditangguhkan pada jangka waktu yang disepakati. ${ }^{27}$ Pembiayaan murabahah merupakan pembiayaan yang potensial menghasilkan pendapatan dibandingkan dengan alternatif pendanaan lainnya, hal ini tepat Pada sisi penyaluran dana (Landing of Fund) kepada masyarakat.

Salah satu penyaluran dana tersebut antara lain berupa sistem jual beli, kerja sama, rahn dan pembiayaan lain yang memberikan

\footnotetext{
27 Amilis Kina, 'MURABAHAH BERMASALAH Studi Pada BMT Syari 'ah Pare', AnNisbah, 03.02 (2017), 394-416.
} 
Menjaga Stabilitas Usaha Pasca Pandemi Covid-19 dengan Penerapan Akad Murabahah pada Pelaksanaan Investasi Syariah

keuntungan bagi sipemilik dana, namun dalam hal ini pembiayaan yang diberikan tetap berfokus pada prinsip-prinsip syariah yang telah ada. Secara etimologis, jual beli berarti menukar harta dengan harta. Adapun secara terminologis, maka ia berarti transaksi penukaran selain dengan fasilitas dan kenikmatan. ${ }^{28}$

Transaksi tukar menukar yang dimaksud agar tidak termasuk di dalamnya suatu penyewaan dan pernikahan, maka dalam artian jual beli tersebut sengaja diberikan pengecualian terhadap "fasilitas" dan "kenikmatan". Dengan etimologi dan terminologi tersebut, semakin memberikan pemahaman yang luas tentang apa yang dimaksud denga transaksi jual beli. Dimana jual beli merupakan salah satu prilaku ekonomi yang melibatkan para pihak untuk melakukan tukar menukar barang dengan uang (alat tukar lainnya), dan pada pelaksanaan tukar menukar tersebut maka antara pihak sudah mengikatkan dirinya dalam suatu perjanjian untuk saling menyerahkan objek dari akad tersebut dengan didasarkan pada suka rela antara satu dengan yang lainnya.

Kitab Undang-Undang Hukum Perdata pada Pasal 1457 Tentang Jual Beli, menjelaskan bahwa jual beli adalah salah satu perjanjian, dengan mana pihak yang satu mengikatkan dirinya untuk menyerahkan suatu kebendaan, dan pihak yang lain untuk membayar harga yang telah dijanjikan. ${ }^{29}$ Peraturan tersebut semakin memperkuat sebuah asumsi, bahwa di dalam transaksi jual beli akan menciptakan suatu prikatan yang akan mengikat antara para pihak dan dituntut untuk patuh pada perikatan yang telah dibuat. Perikatan yang dimaksud merupakan suatu perjanjian yang mengharuskan pihak yang satu melepaskan hak kemilikannya terhadap suatu barang untuk diserahkan ke pihak lain dan pihak lainnya diwajibkan untuk bersedia untuk membayar barang tersebut dengan harga yang telah disepakati oleh para pihak tersebut.

Selanjutnya, Ulama Hanafiah menjelaskan bahwa yang dimaksud jual beli secara istilah adalah pertukaran harta dengan harta secara khusus, atau pertukaran sesuatu yang diinginkan yang

28 Shalah Ash-Shawi and Abdullah Al-Mushlih, Fikih Ekonomi Keuangan Islam (Jakarta: Darul Haq, 2008), 88.

${ }^{29}$ Subekti and R Tjitrosudibio, Kitab Undang-Undang Hukum Perdata (Jakarta: PT. Balai Pustaka, 2014), 365. 
berguna (mufid) dengan cara khusus, yaitu ijab (ucapan atau perbuatan yang menunjukkan penawaran) dan qabul (ucapan atau perbuatan yang menunjukkan penerimaan). ${ }^{30}$ Pada bagian ini, Ulama Hanafiah memberikan penjelasan yang lebih luas tentang jual beli, dimana pertukaran dalam jual beli tersebut tentu terdapat ijab dan qabul, yang pada esensinya hal tersebut merupakan suatu yang urgen dalam sahnya suatu transaksi jual beli.

Secara bahasa, murabahah berasal dari kata ribh yang maknanya tumbuh dan berkembang dalam perniagaan. ${ }^{31}$ Sehingga dapat dipahami bahwa, Murabahah adalah transaksi penjualan barang dengan menyatakan harga perolehan dan keuntungan (profit) yang disepakati oleh pihak penjual dan pembeli. Hal yang membedakan murabahah dengan penjualan yang biasa kita kenal adalah penjual secara jelas memberi tahu kepada pembeli berapa harga pokok barang tersebut dan berapa besar keuntungan yang diinginkannya. ${ }^{32}$ Dengan berorientasi pada mendapatkan suatu keuntungan atau laba yang bisa dimanfaatkan nantinya dari suatu perniagaan, maka jual beli suatu barang atau objek tertentu dengan cara akad murabahah adalah salah satu cara yang dapat diaplikasikan dalam kehidupan berekonomi. Dimana pada pelaksanaan akad murabahah tersebut, antara pembeli dan penjual dapat melakukan tawar menawar atas besaran margin keuntungan sehingga akhirnya diperoleh kesepakatan. Dengan demikian, maka margin yang akan dihasilkan dari pelaksanaan transaksi tersebut didasarkan atas dasar suka sama suka dan dengan landasan rasa ikhlas antara para pihak.

Jadi singkatnya, murabahah adalah akad jual beli barang dengan menyatakan harga perolehan dan keuntungan (margin) yang disepakati oleh penjual dan pembeli. ${ }^{33}$ Selain itu, karena dalam transaksi akad Murabahah ditentukan berapa required rate of profit-nya (keuntungan yang ingin di peroleh), sehingga akad ini merupakan

\footnotetext{
30 Jaih Mubarok and Hasanudin, Fikih Mu'amalah Maliyah Akad Jual Beli (Bandung: Simbiosa Rekatama Media, 2016), 3.

${ }^{31}$ Qurotul Aini, 'Evaluasi Penerapan Akad Pembiayaan (Studi Pada Kopma UIN Sunan Kalijaga Yogyakarta)', Az Zarqa', 9.1 (2017), 20-45.

32 Sri Nurhayati and Wasilah, Akuntansi Syariah Di Indonesia (Jakarta: Salemba Empat, 2017), 174.

33 Adiwarman A and Karim, Bank Islam (Jakarta: PT. Raja Grafindo Persada, 2010), 113.
} 
Menjaga Stabilitas Usaha Pasca Pandemi Covid-19 dengan Penerapan Akad Murabahah pada Pelaksanaan Investasi Syariah

salah satu bentuk natural certainty contracts. Selanjutnya dapat ditarik kesimpulan, bahwa akad murabahah ini adalah salah satu bentuk akad jual beli amanah yang didasarkan pada penetapan harga dalam mencari keuntungan, dan dalam pengambilan keuntungan ini bisa didapatkan dengan cara menjual barang dengan harga perolehan yang sesungguhnya ditambah dengan margin keuntungan yang telah diseakati oleh para pihak.

Terdapat beberapa landasan terkait dengan jual beli murabahah, antara lain al-Qur'an, as-Sunnah dan ijma', yaitu sebagai berikut :

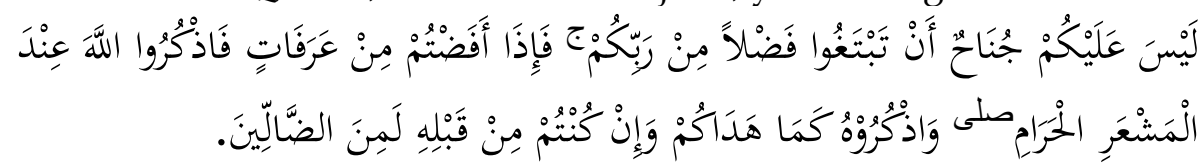

"tidak ada dosa bagimu untuk mencari karunia (riski hasil perniagaan) dari tuhanmu. Maka apabila kamu telah bertolak dari 'Arafat, berzikirlah kepada Allah di Masy'arilharam. Dan berzikirlah (dengan menyebut) Allah sebagaimana yang ditunjukan-Nya kepadamu; dan sesungguhnya kamu sebelum itu benar-benar termasuk orang-orang yang sesat." (QS. Al-Baqarah (02): 198). ${ }^{34}$

Ayat di atas secara tegas memberikan kejelasan bahwa dalam suatu perniagaan, salah satunya yaitu akad jual beli murabahah adalah jalan untuk memperoleh suatu penghasilan dari perniagaan tersebut atau mengaup rezeki yang bisa dimanfaatkan. Selain itu, ayat ini mempertegas bahwa dalam melakukan kegiatan ekonomi dituntut untuk selalu berpedoman pada aturan-aturan Islam. Selain itu, Allah juga berfirman dalam Qur'an Surat al-Baqarah ayat 275;

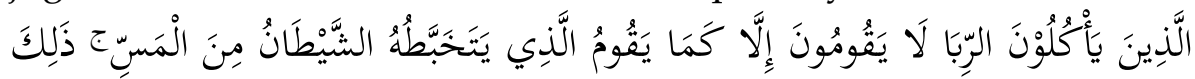

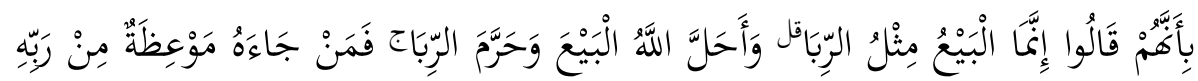

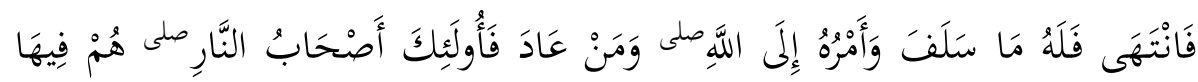

خَالِدُونْ

"Orang-orang yang makan (mengambil riba) tidak dapat berdiri melainkan seperti berdirinya orang yang kemasukan syaitan lantaran (tekanan) (penyakit gila). Keadaan mereka yang demikian itu, adalah

${ }^{34}$ QS. Al-Baqarah (02): 198. 
disebabkan mereka berkata (berpendapat), sesungguhnya jual beli itu sama dengan riba, padahal Allah telah menghalalkan jual beli dan mengharamkan riba. Orang-orang yang telah sampai kepada-Nya larangan dari tuhannya, lalu terus berhenti (dari mengambil riba), maka baginya apa yang telah diambilnya (dahulu)(sebelum datang larangan); dan urusannya (terserah) kepada Allah. Orang yang mengulangi (mengambil riba), maka orang itu adalah penghunipenghuni neraka;mereka kekal di dalamnya." (QS. Al-Baqarah (02): 275). 35

Ayat ini juga memberikan suatu pemahaman bahwa dalam melakukan transaksi ekonomi, setidaknya bisa menjauhkan diri dari suatu pekerjaan-pekerjaan yang menimbulkan riba dan transaksi lain yang dilarang dalam syariah. murabahah adalah salah satu akad jual beli yang diperintahkan oleh Islam untuk diaplikasikan dan diimplementasikan dalam melakukan perbuatan ekonomi, karena secara dalil yang hak (al-Qur'an), Allah sangat memperbolehkan atau menghalalkan transaksi jual beli dan mengharamkan perbuatan riba. Sehingga dalam ayat ini, bisa ditarik kesimpulan bahwa murabahah adalah suatu akad jual beli yang secara hukum Islam halal untuk dilaksanakan, kecuali dalam akad tersebut masih memasukkan perbuatan riba.

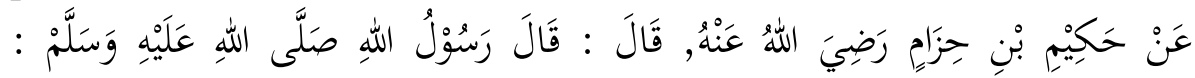

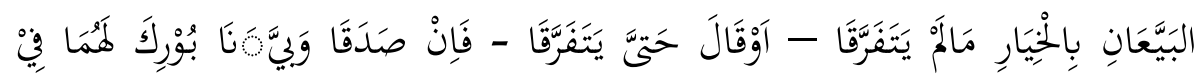

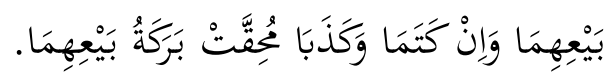

Hakim bin Hizam r.a menuturkan bahwa Rasulullah Saw bersabda, "Penjual dan pembeli itu memiliki hak khiyar selama keduanya belum berpisah."- atau beliau bersabda, "hingga keduanya berpisah."- "jika keduanya jujur dan menjelaskan (cacat barang), maka keduanya akan mendapatkan berkah dalam jual beli mereka. Jika keduanya saling menyembunyikan (cacat barang) atau berdusta, maka berkah jual beli mereka dihilangkan. 36

\footnotetext{
${ }^{35}$ QS. al-Baqarah (02): 275

36 Syaikh Abdul Ghani Al-Maqdisi, Umdatul Ahkam: Hadits Bukhari Muslim Pilihan (Yogyakarta: Media Hidayah, 2005), 202.
} 
Uraian hadits di atas menekankan sikap jujur dalam melakukan transaksi murabahah, sendati demikian agar transaksi yang dilakukan oleh para pihak dapat mendapatkan berkah dan akan bernilai suatu ibadah. Karena Islam tidak berbicara seberapa besar hasil yang diterima, melainkan seberapa besar manfaat yang dapat dirasakan dalam kegiatan yang dikerjakan tersebut.

Umat manusia telah berkosensus tentang keabsahan jual beli, karena manusia sebagai anggota masyarakat selalu membutuhkan apa yang dihasilkan dan dimiliki orang lain. Oleh karena itu jual beli ini adalah salah satu jalan untuk mendapatkan secara sah, dengan demikian mudahlah bagi setiap individu untuk memenuhi kebutuhannya. ${ }^{37}$ Karenanya atas dasar hukum di atas, dapat ditarik kesimpulan bahwa selagi transaksi murabahah tersebut akan memberikan keringanan kepada pembeli untuk memperoleh barang yang diinginkan dan tidak bertentangan dengan ajaran syari' at Islam, maka transaksi murabahah tersebut diperbolehkan walaupun dengan pembayaran yang tidak tunai.

Selanjutnya dalam hukum positif di Indonesia juga mengatur tentang akad jual beli ini, dimana di dalam Pasal 73 dan 74 bagian keempat Kompilasi Hukum Ekonomi Syariah, dinyatakan bahwa syarat yang dikaitkan dengan akad jual beli dipandang sah dan mengikat apabila menguntungkan pihak-pihak. Dan apabila jual beli bersyarat hanya menguntungkan salah satu pihak, maka jual beli tersebut dipandang sah, sedangkan persyaratannya batal. ${ }^{38}$ Dengan demikian sudah jelas, bahwa orientasi dari akad jual beli ini tidak lain dan tidak mungkin, yaitu berorientasi pada terciptanya suatu kemaslahatan dan kesejahteraan bersama.

\section{Penerapan Akad Murabahah Pada Pelaksanaan Investasi Syariah}

Seperti apa yang telah dipahami, bahwa dalam perspektif Islam, Investasi adalah penanaman dana atau penyertaan modal untuk suatu bidang usaha tertentu yang kegiatan usahanya tidak bertentangan dengan prinsip-prinsip syariah, baik objek ataupun

\footnotetext{
37 Yenti Afrida, 'Analisis Pembiayaan Murabahah Di Perbankan Syariah', Jebi (Jurnal $\begin{array}{lllll}\text { Ekonomi Dan Bisnis } & 1.2 \quad \text { (2016), } & \text { 155-66 }\end{array}$ <http://journal.febi.uinib.ac.id/index.php/jebi/article/view/32>.

38 Madani, Kompilasi Hukum Ekonomi Syariah, 33.
} 
prosesnya. ${ }^{29}$ Dari definisi tersebut, bisa ditarik benang mirahnya bahwa dalam pelaksanaan investasi bermaksud untuk menghasilkan profit atau laba yang bisa dimanfaatkan secara baik dan sempurna. Maka dengan menggunakan sistem akad murabahah dalam pengelolaan modal pada pelaksanaan investasi syariah, diharapkan mampu untuk meminimalisir bahkan dapat dicegah untuk hal tersebut terjadi, mengingat kondisi buruk yang telah terjadi akibat pandemi covid-19. Ketika pihak nasabah membeli suatu barang kepada pihak bank, maka hasil pembayaran yang dilakukan oleh pihak nasabah kepada bank adalah laba yang akan dibagi bersama dengan investor.

Selain itu, investasi yang merupakan suatu cara untuk memperoleh keuntungan pada masa yang akan datang dari modal yang ditanamkan sebelumnya. 40 Sebut saja bahwa investasi merupakan penundaan konsumsi yang akan terjadi sekarang untuk yang akhirnya dimasukkan dalam sebuah aktiva produktif selama periode tertentu. ${ }^{41}$ Sedangkan orientasi investasi yang lebih universal ialah meningkatkan kesejahteraan investor. ${ }^{42}$ Konsep penerapan akad murabahah dalam pelaksanaan investasi syariah ini, pada hakekatnya untuk menjaga kestabilan usaha yang dilakukan oleh pengelola modal yang ditanamkan oleh para investor, khususnya untuk memberikan kemaslahatan dan kesejahteraan masyarakat Islam yang melakukan investasi tersebut. konsep ini didasari ayat al-Qur'an yang berbunyi:

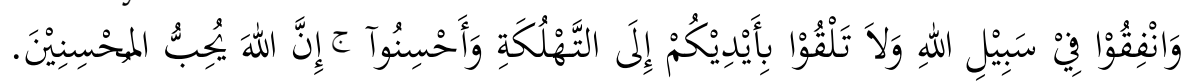

"Dan belanjakanlah (harta bendamu) di jalan Allah, dan janganlah kamu menjatuhkan dirimu sendiri kedalam kebinasaan, dan berbuat

\footnotetext{
${ }^{39}$ Pardiansyah, 'Investasi Dalam Perspektif Ekonomi Islam: Pendekatan Teoritis Dan Empiris', 340.

${ }^{40}$ H. Habiburrahman, 'Analisis Pengaruh Nilai Tukar Rupiah Dan Inflasi Terhadap Indeks Harga Saham Sektor Properti Di Bursa Efek Indonesia', Jurnal Manajemen Dan Bisnis Universitas Bandar Lampung, 5.2 (2015), 112-29.

41 Jogiyanto Hartono, Teori Portofolio Dan Analisis Investasi (Yogyakarta: BPEFYogyakarta, 2014), 204.

42 Eduardus Tandelilin, Analisis Investasi Dan Manajemen Portofolio (Yogyakarta: BPEFYogyakarta, 2001), 3.
} 
Menjaga Stabilitas Usaha Pasca Pandemi Covid-19 dengan Penerapan Akad Murabahah pada

Pelaksanaan Investasi Syariah

baiklah, karena. Sesungguhnya Allah menyukai orang-orang yang berbuat baik". (QS. al-Baqarah (2): 195)43

Ayat di atas semakin mempertegas, bahwa dalam melakukan transaksi ekonomi apapun (dalam hal ini investasi) diupayakan untuk dilakukan dalam kegiatan yang berada alam koridor Islam, yakni tidak bertentangan dengan hukum syariah. Selain itu, di dalam ayat tersebut menjelaskan bahwa di dalam melakukan kegiatan ekonomi khususnya investasi, diupayakan untuk bisa mengambil manfaat dari kegiatan yang dilakukan, bukan malah menjadi alat atas terjadinya kerugian atau kerusakan pada dirinya. Dengannya untuk mengejawantahkan ayat tersebut dalam suatu tindakan nyata, maka penerapan murabahah tersebut mampu untuk menjaga kestabilan usaha dalam pengelolaan modal pada kegiatan investasi yang dilakukan.

Sebagaimana telah diketahui bahwa akad murabahah adalah salah satu sistem jual beli amanah. ${ }^{44}$ Oleh karena itu, untuk memberikan pemahaman yang lebih terhadap konsep dalam menjaga stabilitas usaha dengan penerapan akad murabahah pada pelaksanaan investasi tersebut. maka dapat dipahami dalam gambaran sebagai berikut:

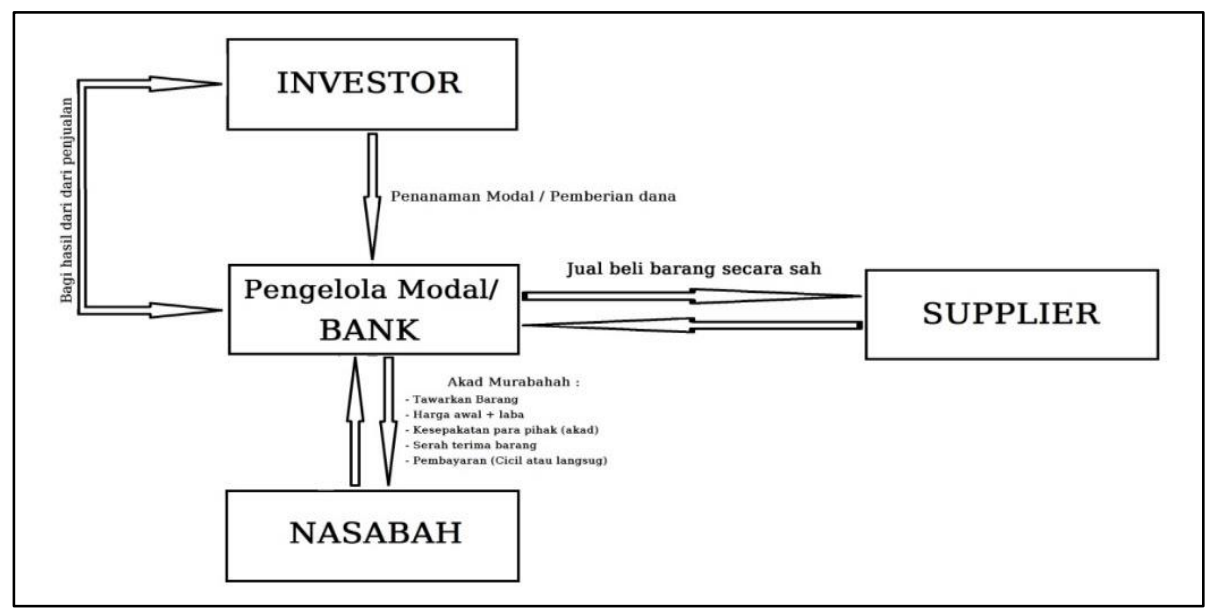

Gambar 1: Mekanisme Pengelolaan Dana

${ }^{43}$ QS. al-Baqarah (2): 195

${ }^{44}$ M. Yazid Afandi, Figh Muamalah Dan Implementasi Dalam Lembaga Keuangan Syariah (Yogyakarta: TPT Logung Pustaka, 2009), 87. 
Mekanisme pembiayaan akad murabahah dalam pengelolaan modal pada pelaksanaan investasi syariah di atas, dapat dijelaskan sebagai berikut:

1. Investor menanamkan sejumlah uang atau menanamkan modal terhadap pengelola modal (Bank) atau Lembaga Keuangan Syariah lainnya. Penanaman modal ini, bisa berupa akad mudharabah atau musyarakah, sesuai dengan harapan para pihak.

2. Bank akan mengelola modal tersebut dalam bentuk pembiayaan murabahah kepada nasabah.

3. Nasabah mengajukan permohonan pembelian barang kepada Bank.

4. Bank mempelajari permohonan nasabah. Apabila diterima, maka Bank membeli barang atau aset sesuai spesifikasi pesanan nasabah secara sah dari Supplier.

5. Bank dan nasabah melakukan transaksi jual beli murabahah meliputi negosiasi harga, sistem dan jangka waktu pembayaran, ijab dan kabul, serah terima barang.

6. Nasabah membayar kewajibannya kepada Bank sesuai dengan perjanjian.

7. Bank dan pihak investor akan melakukan bagi hasil dari pengelolaan modal yang dilakukan oleh Bank.

8. Bagi hasil yang akan dilakukan oleh pihak investor dan pengelola modal (Bank) adalah hasil dari penjualan Bank kepada nasabah. Bagi hasil tersebut sesuai dengan kesepakatan di awal (musyarakah atau mudharabah).

Akad murabahah yang dianggap sebagai instrument sangat bermanfaat bagi setiap orang yang membutuhkan akan tetapi tidak memiliki sejumlah uang. ${ }^{45}$ Pada titik ini, dalam investasi seorang pembisnis atau pengusaha hendaklah untuk memperhatikan usaha dan bisnis yang dijalankan. ${ }^{46}$ Dengan memahami secara mendalam terhadap sistem ini, dimana dengan mengimplemintasikan akad murabahah pada pelaksanaan kegiatan investasi syariah, terdapat

45 Akhmad Mujahidin, Hukum Perbankan Syariah (Jakarta: PT. Raja Grafindo Persada, 2016), 53.

46 Trisno Wardy Putra, 'Investasi Dalam Ekonomi Islam', Ulumul Syar,I, 7.2 (2018), 4957. 
Menjaga Stabilitas Usaha Pasca Pandemi Covid-19 dengan Penerapan Akad Murabahah pada Pelaksanaan Investasi Syariah

beberapa kelebihan yang dapat dijadikan sebagai tolak ukur untuk mengaplikasikannya langsung di dalam Lembaga Keuangan Syariah yang ada di Indonesia.

Kelebihan dari sistem ini, bank dimungkinkan tidak akan terjadi kerugian atau akan meminialisir terjadinya pailid di dalam pengelolaan modal yang dilakukan oleh pihak bank atau lembaga keuangan syariah lainnya, karena di dalam akad murabahah adanya kebijakan dimana pihak bank berhak untuk meminta barang jaminan untuk dijaminkan oleh pihak nasabah kepada bank, dimana pada nantinya nasabah akan terdorong untuk melakukan pembayaran secara lunas. Jika pada nantinya nasabah mengalami wanprestasi dengan alasan tidak mau bayar lagi, maka bank berhak untuk menjual objek akad sebelumnya, atau jika tidak bank akan menawarkan solusi dimana barang jaminan tersebut dijual untuk dijadikan sebagai pelunasan hutang pada bank. Jika nasabah bersedia, maka hal tersebut dpat dilakukan oleh pihak bank dengan nasabah.

Penjualan objek akad pada nasabah yang melakukan wanprestasi tersebut, sesuai dengan Pasal 129 Kompilasi Hukum Ekonomi Syariah, yang berbunyi : Akad murabahah dapat diselesaikan dengan cara menjual objek akad kepada Lembaga Keuangan Syariah dengan harga pasar, atau nasabah melunasi sisa hutangnya kepada Lembaga Keuangan Syariah dari hasil penjualan objek akad tersebut. ${ }^{47}$ sehingga dengan dasar hukum inilah semakin mempertegas bahwa konsep ini merupakan suatu konsep yang pas dan mampu memberikan dampak yang sangat esar terhadap kemajuan, perkembangan dan keselarasan berekonomi yang telah di syariatkan oleh Islam.

\section{Penutup}

Investasi dalam pandangan Islam adalah suatu kometmen atas suatu harta, modal, dana, ataupun sumber daya lainnya yang dilakukan dengan maksud untuk memperoleh keuntungan, kemanfaatan dan kemaslahatan di masa yang akan datang dengan menggunakan prinsip-prinsip syariah. Akad murabahah suatu akad jual beli yang berorentasi pada kesejahteraan masyarakat dan kemaslahatan umat dengan mengimplemintasikan prinsip syariah.

47 Madani, Kompilasi Hukum Ekonomi Syariah, 344. 
Pada kegiatan dan akad ini merupakan suatu kegiatan ekonomi yang sangat dianjurkan di dalam Islam, bahkan benih dasarnya sudah termaktub di dalam al-Qur'an dan al-Hadits.

Jenis transaksi murabahah yang dilakukan dalam pelaksanaan investasi syariah dapat menunjang keberhasilan di dalam berinvestasi. Yang pada esensinya, semua jenis transaksi pada umumnya diperbolehkan sepanjang tidak mengandung unsur riba, maysir, gharar dan transaski lain yang dilarang dalam Syariah. Hal yang demikian juga menegaskan bahwa akad murabahah dalam sebuah investasi adalah salah satu sistem yang tepat untuk menekan stabilnya usaha yang dijalankan dan memperbesar laba yang diinginkan secara bersih atau halal.

\section{Daftar Pustaka}

A, Adiwarman, and Karim, Bank Islam (Jakarta: PT. Raja Grafindo Persada, 2010)

Afandi, M. Yazid, Figh Muamalah Dan Implementasi Dalam Lembaga Keuangan Syariah (Yogyakarta: TPT Logung Pustaka, 2009)

Afrida, Yenti, 'Analisis Pembiayaan Murabahah Di Perbankan Syariah', Jebi (Jurnal Ekonomi Dan Bisnis Islam), 1.2 (2016), 155-66 <http://journal.febi.uinib.ac.id/index.php/jebi/article/view/32 $>$

Aini, Qurotul, 'Evaluasi Penerapan Akad Pembiayaan (Studi Pada Kopma UIN Sunan Kalijaga Yogyakarta)', Az Zarqa', 9.1 (2017), 20-45

Al-Maqdisi, Syaikh Abdul Ghani, Umdatul Ahkam: Hadits Bukhari Muslim Pilihan (Yogyakarta: Media Hidayah, 2005)

Ash-Shawi, Shalah, and Abdullah Al-Mushlih, Fikih Ekonomi Keuangan Islam (Jakarta: Darul Haq, 2008)

Aziz, Abdul, Manajemen Investasi Syariah (Bandung: Alfabeta, 2010)

Djazuli, A, Kaidah-Kaidah Fikih: Kaidah Hukum Islam Dalam Menyelesaikan Masalah-Maslah Yang Praktis (Jakarta: Kencana, 2006)

Habiburrahman, H., 'Analisis Pengaruh Nilai Tukar Rupiah Dan Inflasi Terhadap Indeks Harga Saham Sektor Properti Di Bursa Efek Indonesia', Jurnal Manajemen Dan Bisnis Universitas Bandar Lampung, 5.2 (2015), 112-29 
Menjaga Stabilitas Usaha Pasca Pandemi Covid-19 dengan Penerapan Akad Murabahah pada Pelaksanaan Investasi Syariah

Hartono, Jogiyanto, Teori Portofolio Dan Analisis Investasi (Yogyakarta: BPEF-Yogyakarta, 2014)

Haryati, Mardhiyah, 'Investasi Menurut Perspektif Ekonomi Islam', Journal of IslamicEconomics and Business), 1.1 (2016), 66-78 <http:/ / ejournal.radenintan.ac.id/index.php/ikonomika>

Iltiham, Muhammad Fahmul, 'Implementasi Akad Mudharabah Berdasarkan PSAK 105 Tentang Akuntansi Mudharabah Dan Fatwa DSN MUI Pada Produk Pembiayaan', Jurnal Ekonomi Islam, 11.1 (2019), 21-38

Kasmir, and Jakfar, Studi Kelayakan Bisnis (Jakarta: Kencana Prenada Media, 2015)

Kina, Amilis, 'MURABAHAH BERMASALAH Studi Pada BMT Syari 'ah Pare', An-Nisbah, 03.02 (2017), 394-416

Lisa, Hendro, and Martina Napratilora, 'Sosialisasi Investasi Syariah Di Masyarakat', AL-MUQAYYAD: Jurnal Ekonomi Syariah, 3.1 (2020), 18-43 <https:// doi.org/10.46963/jam.v3i1.152>

M, Hajar, Model-Model Pendekatan Dalam Penelitian Hukum Dan Fiqh (Pekanbaru: UIN Suska Riau, 2015)

Madani, Pusat Pengkajian Hukum Islam Masyarakat, Kompilasi Hukum Ekonomi Syariah (Jakarta: Kencana, 2017)

Mahadani, Ricko, Investasi Emas Batangan Untuk Orang Gajian (Yogyakarta: Khitah Publishing, 2012)

Marzuki, Peter Mahmud, Penelitian Hukum (Jakarta: Kencana Prenada Media, 2010)

Mubarok, Jaih, and Hasanudin, Fikih Mu'amalah Maliyah Akad Jual Beli (Bandung: Simbiosa Rekatama Media, 2016)

Mujahidin, Akhmad, Hukum Perbankan Syariah (Jakarta: PT. Raja Grafindo Persada, 2016)

Nasional, Fatwa Dewan Syari'ah, 'Fatwa DSN Mekanisme Perdagangan Efek', 2011

Nasution, Dito Aditia Darma, Erlina Erlina, and Iskandar Muda, 'Dampak Pandemi COVID-19 Terhadap Perekonomian Indonesia', Jurnal Benefita, $5.2 \quad$ (2020), 212 <https://doi.org/10.22216/jbe.v5i2.5313>

Nurhayati, Sri, and Wasilah, Akuntansi Syariah Di Indonesia (Jakarta: Salemba Empat, 2017) 
Pardiansyah, Elif, 'Investasi Dalam Perspektif Ekonomi Islam: Pendekatan Teoritis Dan Empiris', Economica: Jurnal Ekonomi Islam, $8.2 \quad$ (2017), 355 <https://doi.org/10.21580/economica.2017.8.2.1920>

Putra, Trisno Wardy, 'Investasi Dalam Ekonomi Islam', Ulumul Syar,I, $7.2(2018), 49-57$

Siyoto, Sandu, and Ali Sodik, Dasar Metodologi Penelitian (Yogyakarta: Literasi Media Publishing, 2015)

Soekanto, Soerjono, and Sri Mamudji, Penelitian Hukum Normatif: Suatu Tinjauan Singkat (Jakarta: PT. Raja Grafindo Persada, 2003)

Subekti, and R Tjitrosudibio, Kitab Undang-Undang Hukum Perdata (Jakarta: PT. Balai Pustaka, 2014)

Sukirno, Sadono, Pengantar Teori Makro Ekonomi (Jakarta: PT. Raja Grafindo Persada, 2003)

Syahbudi, Muhammad, and Elida Elfi Barus, 'Mewujudkan Masyarakat Yang Sadar Investasi Syariah', Junal Ilmu Ekonomi Dan Keislaman, 7.2 (2019), 208-23

Tandelilin, Eduardus, Analisis Investasi Dan Manajemen Portofolio (Yogyakarta: BPEF-Yogyakarta, 2001)

- - , Portofolio Dan Investasi: Teori Dan Aplikasi (Yogyakarta: Kanisius, 2010)

Trimulato, Trimulato, 'Analisis Potensi Produk Musyarakah Terhadap Pembiayaan Sektor Riil Umkm', Jurnal Ekonomi \& Studi Pembangunan, $18.1 \quad$ (2017), 41-51 <https:// doi.org/10.18196/jesp.18.1.3830>

Yamali, Fakhrul Rozi, and Ririn Noviyanti Putri, 'Dampak Covid-19 Terhadap Ekonomi Indonesia', Ekonomis: Journal of Economics and Business, $\quad 4.2 \quad$ (2020), 384 <https:// doi.org/10.33087/ekonomis.v4i2.179> 